SPECIAL ARTICLE / ARTIGO ESPECIAL

\title{
Impact of the COVID-19 pandemic on prenatal, diabetes and medical appointments in the Brazilian National Health System
}

\author{
Impacto da pandemia COVID-19 no Pré-natal, Diabetes e consulta médica \\ no Sistema Único de Saúde Brasileiro
}

\author{
Luiz Alexandre Chisini' (D), Eduardo Dickie de Castilhos" (D), Francine dos Santos Costal (D), \\ Otávio Pereira D'Avila"l (I)
}

\begin{abstract}
Objectives: The purpose of this study was to describe the impact of the COVID-19 pandemic on Primary Health Care in Brazil. Methodology: This retrospective ecological study was carried out using Brazilian municipality data obtained from the information systems of the National Public Health System. The outcomes were medical appointments, prenatal procedures and diabetes care. The exposure variable was the occurrence of the COVID-19 pandemic, based on the first case reported in Brazil. Multilevel mixed-effects negative binomial regression was used to analyze the association between the number of procedures per 10,000 inhabitants and COVID-19. Results: Data from 5,564 Brazilian municipalities were included in the present study. Regarding medical appointments, the largest reduction occasioned by the pandemic occurred in May (IRR = $0.27,95 \%$ CI $0.24-0.30$ ). Prenatal procedures were reduced by $65 \%$ (IRR $=0.35,95 \% \mathrm{CI} 0.32-0.38$ ), also in May. In addition, diabetes care saw the biggest reductions in April 2020 (IRR $=0.24,95 \% \mathrm{CI} 0.11-0.53$ ) and May $2020($ IRR $=0.19,95 \%$ CI $0.09-0.43)$. From February to December 2020, the pandemic had a significant effect on the total number of procedures evaluated. Conclusion: The findings showed a reduction in prenatal procedures, diabetes and medical consultations performed in Brazil's Primary Health Care, following the onset of the COVID-19 pandemic.
\end{abstract}

Keywords: Coronavirus infections. Prenatal care. Diabetes mellitus. Medical care. Primary health care.

'Biological and Health Sciences Center, Graduate Program in Dentistry, Universidade do Vale do Taquari - Lajeado (RS), Brazil. "Department of Social and Preventive Dentistry, Graduate Program in Dentistry, Universidade Federal de Pelotas - Pelotas (RS), Brazil. Corresponding author: Luiz Alexandre Chisini. Graduate Program in Dentistry, Universidade do Vale do Taquari, Rua Avelino Talini, 171, CEP: 95914-014, Bairro Universitário, Lajeado, RS, Brazil. E-mail: alexandrechisini@gmail.com

Conflict of interests: nothing to declare - Financial support: none. 
RESUMO: Objetivos: O objetivo do presente estudo foi descrever o impacto da pandemia de covid-19 na Atenção Primária à Saúde (APS) Brasileira. Métodos: Estudo ecológico retrospectivo realizado com dados de municípios brasileiros, obtidos nos sistemas de informação do Sistema Único de Saúde (SUS). Os desfechos do estudo foram as consultas médicas, procedimentos de pré-natal e tratamento de diabetes. A exposição foi a ocorrência da pandemia de covid-19, a partir do primeiro caso notificado no Brasil. Regressões binomiais negativas de efeitos mistos multinível foram utilizadas para analisar a associação entre o número de procedimentos por 10.000 habitantes e a pandemia de covid-19. Resultados: Dados de 5.564 municípios brasileiros foram incluídos no presente estudo. Em relação à consulta médica, a maior redução devido à pandemia em curso ocorreu em maio (IRR = 0,27, IC95\% $0,24-0,30)$. Para os procedimentos de pré-natal, a redução foi de $65 \%$ (IRR = 0,35, IC95\% 0.32 - 0.38), também em maio. Ainda assim, os procedimentos de tratamento do diabetes tiveram maiores reduções em abril (IRR $=0,24$, IC95\% 0,11-0,53) e maio (IRR = 0,19, IC95\% 0,09-0,43) de 2020. De fevereiro a dezembro de 2020, a pandemia de covid-19 impactou significantemente o total de procedimentos avaliados. Conclusão: Os achados mostraram uma redução de procedimentos de pré-natal, diabetes e consultas médicas realizadas na Atenção Primária à Saúde (APS) do Brasil, após o início da pandemia de covid-19.

Palavras-chave: Infecções por coronavírus. Cuidado pré-natal. Diabetes mellitus. Cuidados médicos. Atenção primária à saúde.

\section{INTRODUCTION}

Since 2019, the coronavirus pandemic has changed the global picture and the organization of health services ${ }^{1-4}$. The first case of COVID-19 in Brazil was recorded in February and from then until December 2020, almost 200 thousand lives were lost and almost 8 million cases reported ${ }^{5}$. The problems related to the health systems' capacity to cope with the consequences of the pandemic worldwide are well documented in the literature, and the limitations go far beyond attending to cases of the disease. The problems are also related to attending to the other health demands of the population ${ }^{6}$.

The Unified Health System in Brazil (SUS) covers almost $75 \%$ of the Brazilian population in the country, while the supplementary health care system caters to the remaining $25 \%$. In the context of the pandemic, the System is expected to be equipped to provide assistance to the growing number of cases of COVID-19 while still attending to other acute and chronic conditions'. Unfortunately, deficiencies in Brazil's health care networks, which are still fragmented and inadequate, the lack of coordination between health care hierarchies and underfunding as well have become even more evident during the pandemic ${ }^{7,8}$.

Primary Health Care (PHC) has played an essential role in the context of the pandemic with effective care coordination'. PHC can be responsible for maintaining preventive actions, attending to priority groups and responding to certain emergency cases related to chronic diseases ${ }^{7,10}$. In addition, it plays an important role in containing the 
dissemination and monitoring of mild or asymptomatic cases in home isolation, in addition to engaging with the community. The impact of the pandemic on PHC and health services in Brazil with regard to some aspects of care is not yet known. Thus, the purpose of this study was to describe the impact of the COVID-19 pandemic on PHC with regard to medical appointments, diabetes care and prenatal procedures in the National Health System in Brazil.

\section{METHODS}

\section{STUDY DESIGN}

This was an ecological, retrospective, observational study using secondary data from several public databases, comprising all 5,564 Brazilian municipalities and with data from information systems in the National Public System (Sistema Único de Saúde - SUS). This represents an analysis of 99.9\% of Brazil's 5,570 municipalities. All of the data that comprised the study variables were extracted from secondary databases in the public domain and therefore did not require approval from the Research Ethics Committee. Data collection was carried out by a single researcher in February 2021

\section{OUTCOMES}

The outcomes of the present study were the rate of medical procedures, with information available on the Outpatient Information System (SIA-SUS; http:// sia.datasus.gov.br/principal/index.php). The procedures were categorized into three groups:

- Medical appointments (home appointments/care and medical appointments in Primary Health Care);

- Prenatal procedures (prenatal appointments of partner, prenatal appointments, puerperal appointments, fast-testing for HIV detection in the expectant mother or father/partner, fast-testing of pregnancy, fast-testing for syphilis in the expectant mother or father/partner);

- Diabetes care (diabetes treatment, diabetic foot examination, determination of glucose in urine). We also calculated the total number of the abovementioned procedures.

Thus, the absolute number of procedures per 10,000 inhabitants was calculated monthly (February to December of 2018, 2019 and 2020) for each group. Estimates of inhabitants in 2019 were based on information provided by the Brazilian Institute of Geography and Statistics ${ }^{11}$. 


\section{EXPOSURE}

The exposure variable was the occurrence of the COVID-19 pandemic and seeks to estimate the impact of SARS-CoV-2 infection on the public health system in Brazil. The figure for the rate of procedures in the current pandemic (February to December 2020) was monthly, compared (to avoid seasonal variations) to the rate of procedures in the equivalent months in 2019 and 2018 (pre-pandemic). We are assuming that the first confirmed case of SARS-CoV-2 in Brazil occurred in February 2020.

\section{COVARIABLES}

The confounding variable evaluated in the present study was the population size of municipalities, which was obtained from the Brazilian Institute of Geography and Statistics and categorized as:

- $\leq 20,000$ inhabitants;

- 20,001 to 50,000 inhabitants;

- 50,001 to 150,000 inhabitants;

- >150,000 inhabitants ${ }^{12}$.

Data relating to coverage by the Family Health Strategy and Oral Health Teams were collected monthly (Proportion -\%) at the municipality level. They were obtained from the information and management of primary care databases and were categorized as follows:

- absent (0\%);

- incipient $(<30 \%)$;

- intermediate (30-70\%);

- consolidated $(\geq 70 \%)$.

Municipalities with an HDI below 0.55 were classified as low HDI, between 0.55 and 0.699 as average HDI, between 0.70 and 0.799 as high HDI and with HDI of 0.80 or more as very high. The Gini index (collected from the databases of the United Nations Development Program ${ }^{13}$ ) was used continuously in the model. Brazil is geopolitically divided into five regions, namely: Southeast, South, Central-West, North and Northeast. The proportion of physicians and nurses per 10,000 inhabitants for 2020 was collected from the National Register of Health Establishments (CNES), human resources section. Additionally, we calculated the rate of basic health units per 10,000 inhabitants.

\section{DATA ANALYSIS}

The analysis was performed using STATA 16.0 software (https://www.stata.com). Descriptive analysis was performed using mean rates, standard deviation, minimum, 
maximum and median of the variables. Multilevel mixed-effects negative binomial regression was used to analyze the association between the procedures and the impact of COVID-19, from February 2018 to December 2020. A stepwise backward procedure was used to select variables in the adjusted model. Only variables showing $\mathrm{p}<0.250$ were retained in the final model. Incidence rate ratios and $95 \%$ confidence intervals were estimated in the regressions.

\section{RESULTS}

Of Brazil's 5,570 municipalities, 99.9\% were included in the present sample. Table 1 displays the description of the rates of procedures and the respective characteristics of the covariables. The mean rate of medical appointment procedures per 10 thousand inhabitants/month, considering the period prior to the pandemic, was 424.1 (SD $=5,626.2$ ) procedures and during the pandemic period, $232.7(\mathrm{SD}=1,471.3)$. The rate of prenatal procedures prior to the pandemic was $23.6(\mathrm{SD}=759.8)$, while $13.2(\mathrm{SD}=650.6)$ for the period of the pandemic.

Table 2 displays the incidence rate ratio of the monthly investigated procedures in the period of the pandemic and compared with the respective months in 2018 and 2019. Considering the total rate of procedures, a significant decrease was also observed in February $(\mathrm{IRR}=0.60,95 \% \mathrm{CI} 0.55-0.64)$; this decrease was even greater in March $(\mathrm{IRR}=0.48,95 \% \mathrm{CI}$ $0.45-0.52)$ and April (IRR $=0.27,95 \%$ CI $0.25-0.29$ ) and remained significant throughout the period of assessment.

A similar trend was observed for medical appointments, which fell by $36 \%$ in February $(\mathrm{IRR}=0.64,95 \% \mathrm{CI} 0.57-0.72)$ with the biggest decrease occurring in May $(\mathrm{IRR}=0.27$, $95 \%$ CI $0.24-0.30$ ), remaining significant until December. A steady decrease was also observed in prenatal procedures, starting with a reduction of $36 \%$ in February. The reduction was less evident in June (IRR $=0.63,95 \%$ CI $0.59-0.66)$ and September $($ IRR $=0.61$, $95 \% \mathrm{CI} 0.58-0.65)$. On the other hand, the number of diabetes treatment procedures did not fall significantly in February (IRR $=1.51,95 \%$ CI $0.88-2.61)$ or March $($ IRR $=0.58$, $95 \% \mathrm{CI} 0.33-1.01)$, but saw the biggest decreases in April (IRR $=0.24,95 \% \mathrm{CI} 0.11-0.53)$ and May $(I R R=0.19,95 \%$ CI $0.09-0.43)$, all in 2020. After this period, the reduction was significant only in August (IRR $=0.61,95 \%$ CI $0.38-0.99)$ and December $($ IRR $=0.29$, $95 \%$ CI $0.16-0.54)$.

\section{DISCUSSION}

The findings showed a significant reduction in the availability of medical appointments and the performance of procedures involving prenatal and diabetes care between the periods compared. Considering the total number of procedures, all months (from February to 
December) witnessed a decrease in the rate of procedures. This may be explained by the large number of health professionals having been redeployed to combat the pandemic, not to mention that health professionals run a higher risk of contracting COVID-19 than the general public and consequently being unable to work ${ }^{14}$. In addition, the fear of infection caused individuals to seek health services less frequently, especially in emergency

Table 1. Description of procedure rates and characteristics of health services in Brazilian municipalities $(\mathrm{N}=5,564)$

\begin{tabular}{|c|c|c|c|c|c|}
\hline Variables & Mean & SD & Minimum & Median & Maximum \\
\hline $\begin{array}{l}\text { Rate of medical appointment } \\
\text { procedures per } 10 \text { thousand } \\
\text { inhabitants/month, Feb to Dec } \\
2018 / 2019 \text { (SIA-SUS) }\end{array}$ & 424.1 & $5,626.2$ & 0 & 0 & $805,915.3$ \\
\hline $\begin{array}{l}\text { Rate of medical appointments per } 10 \\
\text { thousand inhabitants/month, Feb to } \\
\text { Dec } 2020 \text { (SIA-SUS) }\end{array}$ & 232.7 & $1,471.3$ & 0 & 0 & $156,979.9$ \\
\hline $\begin{array}{l}\text { Rate of prenatal procedures per } 10 \\
\text { thousand inhabitants/month, Feb to } \\
\text { Dec } 2018 / 219 \text { (SIA-SUS) }\end{array}$ & 23.6 & 759.8 & 0 & 0 & $158,461.7$ \\
\hline $\begin{array}{l}\text { Rate of prenatal procedures per } 10 \\
\text { thousand inhabitants/month, Feb to } \\
\text { Dec } 2020 \text { (SIA-SUS) }\end{array}$ & 13.2 & 650.6 & 0 & 0 & $155,895.1$ \\
\hline $\begin{array}{l}\text { Rate of diabetes care per } 10 \\
\text { thousand inhabitants/month, Feb to } \\
\text { Dec } 2018 / 2019 \text { (SIA-SUS) }\end{array}$ & 2.8 & 212.1 & 0 & 0 & $67,138.4$ \\
\hline $\begin{array}{l}\text { Rate of diabetes care per } 10 \\
\text { thousand inhabitants/month, Feb to } \\
\text { Dec } 2020 \text { (SIA-SUS) }\end{array}$ & 0.13 & 5.1 & 0 & 0 & $1,094.6$ \\
\hline $\begin{array}{l}\text { Family health strategy coverage as \% } \\
\text { of inhabitants, } 2020 \text { (SIAB) }\end{array}$ & 89.7 & 20.9 & 0 & 100 & 100 \\
\hline $\begin{array}{l}\text { IDH of Brazilian municipalities } 2010 \\
\text { (UNDP) }\end{array}$ & 0.66 & 0.07 & 0.42 & 0.66 & 0.86 \\
\hline $\begin{array}{l}\text { Gini index of Brazilian municipalities } \\
2010 \text { (UNDP) }\end{array}$ & 0.50 & 0.07 & 0.28 & 0.50 & 0.81 \\
\hline $\begin{array}{l}\text { Rate of basic health units per } 10 \\
\text { thousand inhabitants, } 2020 \text { (CNES) }\end{array}$ & 0.000035 & 0.0001951 & 0 & 0.0003325 & 0.0018981 \\
\hline $\begin{array}{l}\text { Rate of physicians per } 10 \text { thousand } \\
\text { inhabitants, } 2020 \text { (CNES) }\end{array}$ & 0.011 & 0.0049 & 0 & 0.010 & 0.066 \\
\hline $\begin{array}{l}\text { Rate of nurses per } 10 \text { thousand } \\
\text { inhabitants, } 2020 \text { (CNES) }\end{array}$ & 0.0009 & 0.0005 & 0 & 0.0008 & 0.006 \\
\hline
\end{tabular}

SD: standard deviation: SIA: Outpatient Information System; SUS: Sistema Único de Saúde; CNES: National Register of Health Establishments. 
Table 2. Incidence rate ratio (IRR) and $95 \%$ confidence interval $(95 \% \mathrm{Cl})$ for total no. of procedures, medical appointments, prenatal procedures and diabetes care, in models of multilevel mixedeffects negative binomial regression for Brazilian municipalities $(N=5,564)$.

\section{Impact of COVID-19 compared to the period prior to the pandemic}

\begin{tabular}{|c|c|c|c|c|c|c|}
\hline \multirow{2}{*}{$\begin{array}{l}\text { Group of procedures } \\
\text { (reference: prior to } \\
\text { pandemic) }\end{array}$} & \multicolumn{3}{|c|}{ Crude } & \multicolumn{3}{|c|}{ Adjusted } \\
\hline & IRR & $95 \% \mathrm{Cl}$ & P-value & IRR & $95 \% \mathrm{Cl}$ & P-value \\
\hline & \multicolumn{6}{|c|}{ February 2020} \\
\hline Total procedures & 0.60 & $0.56-0.65$ & $<0.001$ & 0.60 & $0.55-0.60$ & $<0.001$ \\
\hline Medical appointments & 0.72 & $0.64-0.82$ & $<0.001$ & 0.64 & $0.57-0.72$ & $<0.001$ \\
\hline Prenatal procedures & 0.64 & $0.59-0.68$ & $<0.001$ & 0.64 & $0.59-0.68$ & $<0.001$ \\
\hline \multirow[t]{2}{*}{ Diabetes care } & 1.51 & $0.88-2.61$ & 0.135 & 1.43 & $0.82-2.48$ & 0.199 \\
\hline & \multicolumn{6}{|c|}{ March 2020} \\
\hline Total procedures & 0.48 & $0.45-0.52$ & $<0.001$ & 0.48 & $0.45-0.52$ & $<0.001$ \\
\hline Medical appointments & 0.64 & $0.57-0.72$ & $<0.001$ & 0.54 & $0.47-0.61$ & $<0.001$ \\
\hline Prenatal procedures & 0.48 & $0.44-0.52$ & $<0.001$ & 0.48 & $0.45-0.51$ & $<0.001$ \\
\hline \multirow[t]{2}{*}{ Diabetes care } & 0.62 & $0.34-1.09$ & 0.100 & 0.58 & $0.33-1.01$ & 0.056 \\
\hline & \multicolumn{6}{|c|}{ April 2020} \\
\hline Total procedures & 0.27 & $0.25-0.29$ & $<0.001$ & 0.27 & $0.25-0.29$ & $<0.001$ \\
\hline Medical appointments & 0.38 & $0.33-0.42$ & $<0.001$ & 0.33 & $0.29-0.37$ & $<0.001$ \\
\hline Prenatal procedures & 0.48 & $0.44-0.51$ & $<0.001$ & 0.38 & $0.35-0.42$ & $<0.001$ \\
\hline \multirow[t]{2}{*}{ Diabetes care } & 0.23 & $0.10-0.54$ & 0.001 & 0.24 & $0.11-0.53$ & $<0.001$ \\
\hline & \multicolumn{6}{|c|}{ May 2020} \\
\hline Total procedures & 0.23 & $0.21-0.24$ & $<0.001$ & 0.23 & $0.21-0.25$ & $<0.001$ \\
\hline Medical appointments & 0.34 & $0.30-0.39$ & $<0.001$ & 0.27 & $0.24-0.30$ & $<0.001$ \\
\hline Prenatal procedures & 0.51 & $0.46-0.57$ & $<0.001$ & 0.35 & $0.32-0.38$ & $<0.001$ \\
\hline \multirow[t]{2}{*}{ Diabetes care } & 0.21 & $0.08-0.52$ & 0.001 & 0.19 & $0.09-0.43$ & $<0.001$ \\
\hline & \multicolumn{6}{|c|}{ June 2020} \\
\hline Total procedures & 0.48 & $0.45-0.51$ & $<0.001$ & 0.48 & $0.45-0.51$ & $<0.001$ \\
\hline Medical appointments & 0.56 & $0.49-0.63$ & $<0.001$ & 0.41 & $0.38-0.44$ & $<0.001$ \\
\hline Prenatal procedures & 0.63 & $0.59-0.66$ & $<0.001$ & 0.63 & $0.59-0.66$ & $<0.001$ \\
\hline Diabetes care & 0.62 & $0.34-1.14$ & 0.129 & 0.61 & $0.35-1.07$ & 0.086 \\
\hline
\end{tabular}


Table 2. Continuation.

Impact of COVID-19 compared to the period prior to the pandemic

\begin{tabular}{|c|c|c|c|c|c|c|}
\hline & \multicolumn{6}{|c|}{ July 2020} \\
\hline Total procedures & 0.49 & $0.47-0.53$ & $<0.001$ & 0.49 & $0.46-0.52$ & $<0.001$ \\
\hline Medical appointments & 0.66 & $0.58-0.74$ & $<0.001$ & 0.44 & $0.41-0.48$ & $<0.001$ \\
\hline Prenatal procedures & 0.59 & $0.56-0.63$ & $<0.001$ & 0.59 & $0.56-0.63$ & $<0.001$ \\
\hline \multirow[t]{2}{*}{ Diabetes care } & 0.73 & $0.41-1.31$ & 0.299 & 0.71 & $0.43-1.20$ & 0.212 \\
\hline & \multicolumn{6}{|c|}{ August 2020} \\
\hline Total procedures & 0.48 & $0.46-0.51$ & $<0.001$ & 0.48 & $0.46-0.51$ & $<0.001$ \\
\hline Medical appointments & 0.54 & $0.48-0.61$ & $<0.001$ & 0.45 & $0.41-0.48$ & $<0.001$ \\
\hline Prenatal procedures & 0.56 & $0.53-0.59$ & $<0.001$ & 0.56 & $0.53-0.59$ & $<0.001$ \\
\hline \multirow[t]{2}{*}{ Diabetes care } & 0.62 & $0.37-0.99$ & 0.049 & 0.61 & $0.38-0.99$ & 0.047 \\
\hline & \multicolumn{6}{|c|}{ September 2020} \\
\hline Total procedures & 0.54 & $0.51-0.57$ & $<0.001$ & 0.54 & $0.51-0.57$ & $<0.001$ \\
\hline Medical appointments & 0.65 & $0.58-0.74$ & $<0.001$ & 0.50 & $0.46-0.54$ & $<0.001$ \\
\hline Prenatal procedures & 0.61 & $0.58-0.64$ & $<0.001$ & 0.61 & $0.58-0.65$ & $<0.001$ \\
\hline \multirow[t]{2}{*}{ Diabetes care } & 0.81 & $0.47-1.39$ & 0.458 & 0.79 & $0.47-1.32$ & 0.378 \\
\hline & \multicolumn{6}{|c|}{ October 2020} \\
\hline Total procedures & 0.50 & $0.47-0.53$ & $<0.001$ & 0.50 & $0.47-0.53$ & $<0.001$ \\
\hline Medical appointments & 0.59 & $0.52-0.67$ & $<0.001$ & 0.45 & $0.41-0.48$ & $<0.001$ \\
\hline Prenatal procedures & 0.59 & $0.56-0.63$ & $<0.001$ & 0.59 & $0.56-0.62$ & $<0.001$ \\
\hline \multirow[t]{2}{*}{ Diabetes care } & 0.91 & $0.54-1.54$ & 0.741 & 0.92 & $0.52-1.57$ & 0.758 \\
\hline & \multicolumn{6}{|c|}{ November 2020} \\
\hline Total procedures & 0.53 & $0.50-0.57$ & $<0.001$ & 0.54 & $0.50-0.57$ & $<0.001$ \\
\hline Medical appointments & 0.68 & $0.60-0.77$ & $<0.001$ & 0.65 & $0.57-0.74$ & $<0.001$ \\
\hline Prenatal procedures & 0.62 & $0.59-0.66$ & $<0.001$ & 0.62 & $0.58-0.65$ & $<0.001$ \\
\hline \multirow[t]{2}{*}{ Diabetes care } & 0.74 & $0.43-1.29$ & 0.301 & 0.73 & $0.45-1.20$ & 0.227 \\
\hline & \multicolumn{6}{|c|}{ December 2020} \\
\hline Total procedures & 0.37 & $0.35-0.39$ & $<0.001$ & 0.37 & $0.34-0.39$ & $<0.001$ \\
\hline Medical appointments & 0.59 & $0.52-0.68$ & $<0.001$ & 0.60 & $0.53-0.69$ & $<0.001$ \\
\hline Prenatal procedures & 0.46 & $0.43-0.49$ & $<0.001$ & 0.45 & $0.43-0.49$ & $<0.001$ \\
\hline Diabetes care & 0.28 & $0.14-0.55$ & $<0.001$ & 0.29 & $0.16-0.54$ & $<0.001$ \\
\hline
\end{tabular}

*Human Development Index; Population size; Gini index; Coverage by the Family Health Strategy; Rate of basic health units; rate of nurses; rate of doctors; Brazilian regions. 
situations. Thus, elective treatments were postponed ${ }^{15}$. To corroborate this, no organized action by PHC to confront COVID-19 was implemented at the national level in Brazil. Similarly, monitoring and control actions were directed towards people with health conditions who needed assistance on an ongoing basis. These may be some of the reasons for the results observed in this study ${ }^{14}$.

Emerging countries, such as Brazil, still face an agenda that involves an epidemiological transition caused by an aging population and a triple burden of diseases or health conditions defined by acute health conditions (infectious diseases), external causes and health conditions that need continuous care, organized on the basis of a strong PHC structure ${ }^{16}$. PHC services in Brazil are still largely focused on addressing acute conditions and are largely inefficient in health care conditions that require continuous care ${ }^{17}$.

The significant decrease in PHC during the pandemic period under analysis may further compromise the population's health conditions. Continuous care during pregnancy - prenatal care - has been reported as a protective factor for maternal and child health ${ }^{18,19}$ and has been negatively affected during the entire pandemic period in 2020. Outcomes for the increase in neonatal, postnatal and premature birth mortality have been associated with the purview of $\mathrm{PHC}^{20}$. Moreover, hospital admissions for conditions within the ambit of PHC have been presented as a mark of effectiveness for these services ${ }^{21,22}$. These conditions are represented by an extensive list that includes chronic diseases and their complications. More specifically in Brazil, it has been possible to observe a significant reduction in hospitalizations due to care-sensitive conditions in recent years ${ }^{23}$. However, a reduction in the rate of these improvements, along with difficulties in the management of chronic diseases, has been indicated as a major concern for PHC in the country ${ }^{24}$.

Among the health conditions that require continuous care, at the PHC level, prenatal care, diabetes and hypertension are prominent. In December 2019, the Ministry of Health launched a reform of the Brazilian PHC to improve access and efficiency in the sector $^{25}$. A set of indicators was presented linked to payment for performance ${ }^{25,26}$ aimed at monitoring these conditions. However, due to an initial rule of transition between the different payment models and, subsequently, the declaration of a state of pandemic in the country, the resources linked to the Performance Pay Program (P4P) were guaranteed in their entirety, with the PHC being exempt from presenting the results of the indicators ${ }^{27}$. These factors already demonstrate the great difficulty of the Brazilian PHC model with the quality of the services provided. Data presented in this study corroborate the difficulty of achieving better results, and the scenario presented by the pandemic is adding to this challenge ${ }^{28}$.

Controlled detachment causes numerous concerns in the world in terms of the potential unintended consequences for the interruption, or partial functioning, or change of focus of PHC services. The World Health Organization (WHO) has observed a $75 \%$ reduction in services for non-communicable diseases such as diabetes 
and hypertension ${ }^{29}$. This reduction has been more profound in lower-income countries $^{29}$. The aforementioned data reinforce the concern about a delayed treatment and monitoring agenda for patients who live in conditions that require continuous health care. Specifically, regarding the conditions addressed in this study (diabetes and prenatal), this postponed agenda may bring about an increase in mortality, infant mortality and disability in 2021.

The WHO noted that the underlying causes for existing disruptions to non-communicable disease services vary between income groups, with disruptions to transportation, insufficient personal protective equipment, insufficient staff, and lack of inventory and availability of essential drugs and services, which impact low- and middle-income countries to a greater degree $^{29}$. The solutions pointed out by the authors permeate the adoption of patient screening models, the use of appropriate electronic records, expanded access to medical consultation through the use of telemedicine systems, development of specific protocols for the health care of specific non-communicable diseases for the duration of the pandemic ${ }^{30}$. Fundamentally, one should keep in mind the essential attributes of PHC: access, longitudinality, integrality and coordination of care.

With regard to the limitations of the present study, we used public secondary data from the Ministry of Health. In pandemic conditions, there may be a relaxation regarding the professionals' commitment to communicating and updating the data. Some important information regarding conditions of interest to the topic, such as hypertension, was not available. The data regarding the number of procedures are the only ones made available by the Ministry of Health at the municipal level. In ecological studies, although data do not directly measure quality and access to care, they can point to root problems in PHC services. Ecological designs also have the potential for systematic differences between areas in the measurement or recording of variables. The estimates do not indicate a causal effect, and inferences at the individual level cannot be made from the results of aggregate data, as it is not a causal interference study.

This is the first study known to the authors that shows a reduction in prenatal procedures, diabetes and medical consultations in middle-income countries. These data are extremely important to alert the scientific community and managers about the postponed agenda for 2021. Studies with primary data or data that can point out the possible effects on mortality, infant mortality, drop in immunization and the development of disabilities, are fundamental for detailing this gap. Although the recording of procedures for actions directed towards chronic and prenatal diseases points to a reduction in actions, the formalization of new procedures such as Teleconsultation in Primary Care can benefit the reorganization of PHC services in the SUS, to reduce the repressed demand and mitigate a post-pandemic rebound effect resulting from the discontinuation of care. It is important that, in addition to PHC practices, the effect of the pandemic is monitored in relation to morbidity and mortality patterns in hospital services resulting from preventable causes in PHC, aiming to direct and restructure health practices even during the period of restrictive measures to combat COVID-19. 


\section{REFERENCES}

1. Rodriguez-Morales A, Bonilla-Aldana D, Tiwari R, Sah R, Rabaan A, Kuldeep D. COVID-19, an Emerging Coronavirus Infection: Current Scenario and Recent Developments - An Overview. J Pure Appl Microbiol 2020; 14(1): 4.

2. Lieberman-Cribbin W, Alpert N, Gonzalez A, Schwartz RM, Taioli E. Three months of informational trends in COVID-19 across New York City. J Public Health 2020; 42(3): 448-50. https:// doi.org/10.1093/pubmed/fdaa082

3. Mahajan UV, Larkins-Pettigrew M. Racial demographics and COVID-19 confirmed cases and deaths: a correlational analysis of 2886 US counties. J Public Health 2020; 42(3): 445-7. https://doi.org/10.1093/ pubmed/fdaa070

4. Chisini LA, Sartori LRM, Costa FDS, Salvi LC, Demarco FF. COVID-19 pandemic impact on prosthetic treatments in the Brazilian Public Health System. Oral Dis. 2020. http:/ / doi.org/10.1111/odi.13668

5. World Health Organization. Coronavirus disease (COVID-19) [Internet]. World Health Organization; 2020 [cited on Sept 15, 2020]. Available at: https:// www.who.int/docs/default-source/ coronaviruse/ situation-reports / 20200802-covid-19-sitrep-195.

pdf?sfvrsn=5e5da0c5_2

6. Larry Green Center. Quick COVID-19 survey [Internet]. Larry Green Center; 2020 [cited on June 17, 2020]. Available at: https://www.green-center. org/covid-survey

7. Daumas RP, Silva GAE, Tasca R, Leite IDC, Brasil P, Greco DB, et al. The role of primary care in the Brazilian healthcare system: limits and possibilities for fighting COVID-19. Cad Saude Publica 2020; 36(6): e00104120. https: / / doi.org/10.1590/0102-311X00104120

8. Viana ALD, Bousquat A, Melo GA, Negri Filho A, Medina MG. Regionalization and Health Networks. Ciênc Saúde Coletiva 2018; 23(6): 1791-8. http: / / doi. org/10.1590/1413-81232018236.05502018

9. Ceulemans M, Verbakel J, Van Calsteren K, Eerdekens A, Allegaert K, Foulon V. SARS-CoV-2 Infections and Impact of the COVID-19 Pandemic in Pregnancy and Breastfeeding: Results from an Observational Study in Primary Care in Belgium. Int J Environ Res Public Health 2020; 17(18): 6766. https: / / doi.org/10.3390/ ijerph17186766

10. Souza CDF, Gois-Santos VT, Correia DS, MartinsFilho PR, Santos VS. The need to strengthen Primary Health Care in Brazil in the context of the COVID-19 pandemic. Braz Oral Res 2020; 34: e047. http:/ / doi. org/10.1590/1807-3107bor-2020.vol34.0047
11. Chisini LA, Costa FDS, Demarco GT, Silveira ER, Demarco FF. COVID-19 pandemic impact on paediatric dentistry treatments in the Brazilian Public Health System. Int J Paediatr Dent 2020; 31(1): 31-4. https: / / doi.org/10.1111/ipd.12741

12. Chisini LA, San Martin AS, Pires ALC, Noronha TG, Demarco FF, Conde MCM, et al. A 19-years study of the dental procedures performed in the Brazilian Unified Health System. Cad Saúde Coletiva 2019; 27(3): 34553. https: / / doi.org/10.1590/1414-462x201900030215

13. Martines MR, Ferreira RV, Toppa RH, Assunção LM, Desjardins MR, Delmelle EM. Detecting space-time clusters of COVID-19 in Brazil: mortality, inequality, socioeconomic vulnerability, and the relative risk of the disease in Brazilian municipalities. J Geogr Syst. 2021. https: / / doi.org/10.1007/s10109-020-00344-0

14. Dyer O. Covid-19: Brazil's president rallies supporters against social distancing. BMJ 2020; 369: m1589. https:/ / doi.org/10.1136/bmj.m1589

15. Garrafa E, Levaggi R, Miniaci R, Paolillo C. When fear backfires: Emergency department accesses during the Covid-19 pandemic. Health Policy 2020; 124(12): 13339. http:/ / doi.org/10.1016/j.healthpol.2020.10.006

16. Giovanella L, Mendonça MHM, Buss PM, Fleury S, Gadelha CAG, Galvão LAC, et al. From Alma-Ata to Astana. Primary health care and universal health systems: an inseparable commitment and a fundamental human right. Cad Saude Publica 2019; 35(3): e00012219. http:/ / doi.org/10.1590/0102-311X00012219

17. Facchini L, Tomasi E, Dilélio A. Quality of Primary Health Care in Brazil: advances, challenges and perspectives. Saúde Debate 2018; 42(Spe. No. 1): 20822. https: / / doi.org/10.1590/0103-11042018s114

18. Austin AE, Gottfredson NC, Zolotor AJ, Halpern CT, Marshall SW, Parrish JW, et al. Preconception and Prenatal Predictors of Early Experiences of Risk and Protection Among Alaska Children. Matern Child Health J 2020; 24(1): 82-9. https: / / doi.org/10.1007/ s10995-019-02823-3

19. Ickovics JR, Lewis JB, Cunningham SD, Thomas J, Magriples U. Transforming prenatal care: Multidisciplinary team science improves a broad range of maternal-child outcomes. Am Psychol 2019; 74(3): 343-55. http:// doi.org/10.1037/amp0000435

20. Tuon RA, Ambrosano GM, Silva SM, Pereira AC. [Telephone monitoring service for pregnant women and impact on prevalence of prematurity and associated risk factors in Piracicaba, Sao Paulo State, Brazil]. Cad Saude Publica 2016; 32(7). http:/ / doi. org/10.1590/0102-311X00107014 
21. Billings J, Zeitel L, Lukomnik J, Carey TS, Blank AE, Newman L. Impact of socioeconomic status on hospital use in New York City. Health Aff (Millwood) 1993; 12(1): 162-73. http:/ / doi.org/10.1377/hlthaff.12.1.162

22. Roos LL, Walld R, Uhanova J, Bond R. Physician visits, hospitalizations, and socioeconomic status: ambulatory care sensitive conditions in a Canadian setting. Health Serv Res 2005; 40(4): 1167-85. http: / / doi.org/10.1111/j.1475-6773.2005.00407.x

23. Bastos ML, Menzies D, Hone T, Dehghani K, Trajman A. Correction: The impact of the Brazilian family health on selected primary care sensitive conditions: A systematic review. PLoS One 2017; 12(12): e0189557. http:/ / doi.org/10.1371/journal.pone.0189557

24. World Bank Group. A Fair Adjustment: Efficiency and Equity of Public Spending in Brazil. World Bank Group; 2017.

25. Harzheim E, D’Avila OP, Ribeiro DC, Ramos LG, Silva LED, Santos C, et al. New funding for a new Brazilian Primary Health Care. Ciênc Saúde Coletiva 2020; 25(4): 1361-74. http:// doi. org/10.1590/1413-81232020254.35062019

26. Sellera PEG, Pedebos LA, Harzheim E, Medeiros OL, Ramos LG, Martins C, et al. Monitoring and evaluation of Primary Health Care attributes at the national level: new challenges. Ciênc Saúde Coletiva 2020; 25(4): 1401-12. http:// doi. org $/ 10.1590 / 1413-81232020254.36942019$
27. Brazil. Technical Note no. 5/2020-DESF/SAPS/MS [Internet]. Brazil: Ministério da Saúde; 2020. [cited on Sept. 22, 2020]. Available on: https: / / egestorab.saude. gov.br $/$ image $/$ ?file=20200204_N_SEIMS-0013327270NotaTecnicaIndicadores_3604088260565235807.pdf 28. Noronha K, Guedes GR, Turra CM, Andrade MV, Botega L, Nogueira D, et al. The COVID-19 pandemic in Brazil: analysis of supply and demand of hospital and ICU beds and mechanical ventilators under different scenarios. Cad Saúde Pública 2020; 36(6): e00115320. http: / / doi.org/10.1590/0102-311X00115320

29. World Health Organization. The impact of the COVID19 pandemic on noncommunicable disease resources and services: results of a rapid assessment. Geneva: World Health Organization; 2020.

30. Hong WZ, Chan GC, Chua HR. Continuing Chronic Disease Care During COVID-19 and Beyond. J Am Med Dir Assoc 2020; 21(7): 991-2. https: / / doi.org/10.1016/j. jamda.2020.05.013

Received on: 02/10/2021

Accepted on: 03/01/2021

Preprint on: 03/09/2021

Authors' contributions: LAC and FSC conceived the ideas, analyzed the data, collected the data and wrote the paper. OPD and EDC conceived the ideas, collected the data and wrote the paper. 